\title{
New developments in the pathology of malignant lymphoma: a review of the literature published from August to December 2008
}

\author{
J. Han van Krieken
}

Published online: 5 March 2009

(C) Springer-Verlag 2009

\section{Introduction}

The knowledge of professionals generally has a half-time of about 5 years. So half of everything you will read in this review will be outdated 5 years from now. That may be not so bad, but it also means that everything you have learned more than 5 years ago is only half true, and do you know which half? Keeping up with the literature is an almost impossible task and never complete. With the introduction of the new WHO classification at the EAHP/SH workshop in Bordeaux last year, several major changes are introduced into our daily work. This will be the subject of review in the next issue of the Journal of Hematopathology. For now, there is also quite some interesting data to digest:

\section{Biology of lymphoma}

Hodgkin lymphoma

The successful meeting of the EAHP in Bordeaux focused on tumor microenvironment, an exiting but difficult area. We know how important the stroma and its cells are for tumor growth, but the complexity of the interplays between cells, reporter molecules, and matrix is so large that we have only limited understanding. We may have to await further large steps in systems biology to get a grasp of this by modeling. Nevertheless, interesting work is done in especially Hodgkin lymphoma (HL), a tumor in which the

J. Han van Krieken $(\triangle)$

Department of Pathology,

Radboud University Nijmegen Medical Centre,

P. O. Box 91016500, HB Nijmegen, The Netherlands

e-mail: j.vankrieken@pathol.umcn.nl environment is remarkably large. Chetaille et al. [1] studied 63 cases of classical HL(cHL) by microarray and found that EBV-positive cases differed in profile from EBV-negative cases by the presence of a Th1 response gene signature. Furthermore, they found that when an overexpression of genes related to B cells and apoptosis were present, patients had a favorable outcome. They were able to confirm this by immunohistochemistry: poorer prognosis in the case of high percentage of either TIA-1-positive reactive cells or topoisomerase-2-positive tumor cells, whereas high numbers of BCL11A, FOXP3, or CD20-positive reactive cells had a favorable influence. Immunodetection of BCL11A, a marker of both B cells and plasmacytoid dendritic cells, had the strongest predictive value. EBV-positive cHL $(n=108)$ was also studied by Asano et al. [2], and in comparison with age-related EBV-positive B-cell proliferations $(n=34)$, since also the latter often has an inflammatory background similar to cHL. cHL had a lower ratio of geographical necrosis, lower number of cytotoxic $\mathrm{T}$ cells, and a better prognosis. Many more of such studies will be needed before there will be a reliable marker set that predicts who of the relatively few patients with $\mathrm{cHL}$ will relapse.

\section{B-cell lymphomas}

Also in B-cell lymphomas, the microenvironment is subject of a study: de Jong et al. [3] studied with immunohistochemistry 61 pretreatment biopsies from patients treated in a clinical trial and found that the prognostic impact was different for the two treatment arms. CD69 expression on tumor cells was a poor prognostic sign, and an interfollicular infiltrate of FoxP3-positive $\mathrm{T}$ cells was a good prognostic sign irrespective of the treatment arm, and the authors suggest that a dense infiltrate of FoxP3-positive $\mathrm{T}$ cells, dense and interfollicular infiltrate of CD68-positive 
macrophages, and complete follicular dendritic meshworks were associated with a favorable time to progression in CVP-treated patients, while being a poor prognostic sign in fludarabine-treated patients. This finding confirms the importance of moving away from prognostic marker studies and go to predictive markers (van Krieken [4]). Ai et al. [5] did in vivo experiments that partially explain the findings of de Jong et al: follicular lymphoma B cells in contrast to normal B cells could induce conventional $\mathrm{T}$ cells to express FoxP3 and to acquire regulatory function.

The cell of origin in multicentric Castleman disease (MCD) was hypothesized to be the HHV-8-positive B cell by Chadburn et al. [6]. The phenotype of this cell was similar to that of primary effusion lymphomas (PAX5, Bcl6-; PRDM1/BLIMP1, IRF4/MUM1+; Ki67+) but varied in maturation, since in MCD, cells expressed also Oct2 and cytoplasmic immunoglobulin. Mack and Sugden [7] showed that EBV and HHV8 are both needed for sustained cell proliferation in primary effusion lymphomas.

In vitro studies are used to predict efficacy of drugs. Even though there is often limited correlation with in vivo studies, these experiments do give insight in the biology of tumors. Everton et al. [8] studied the effect of rituximab on the proteasome of follicular lymphoma cells and showed a change in expression for a multitude of proteins, including molecules involved in migration, adhesion, signaling, ubiquitination, and others. Lapalombella et al. [9] combined two drugs, rituximab and lenolidomide, both as single agent effective in CLL, and showed that lenolidomide results in downregulation of CD20 on CLL cells, resulting in lower efficacy. This results predict that this combination is not effective in clinical studies. In cell lines of MCL, Jones et al. [10] showed that a new agent, MI-63, induces p53 and HDM-2 accumulation and inhibition of proliferation which was synergistic with $\mathrm{m}$-TOR inhibitors.

Roue et al. [11] were able to show that bendamustine, a multifunctional alkylating agent, has cytotoxic activity in cell lines of MCL and CLL and that in p53 mutated cell lines, there was a synergistic effect with nucleoside analogues.

CyclinD1 overexpression is the hallmark of MCL, and Dal Col and Colcetti [12] tried to downregulate cyclinD1 in vivo. They show that inhibition of PI3-K/Akt induces a $40 \%$ decrease of cyclin D1 half-life as a result of accumulation of the dephosphorylated/active form of GSK-3beta within the nucleus, where this kinase can phosphorylate cyclin D1. Translocation of cyclin D1 into the cytoplasm is mediated by the nuclear exportin CRM1, whose association with cyclin D1 increases following PI3$\mathrm{K} /$ Akt inhibition. Notably, rapamycin downregulated GSK3beta Ser9 phosphorylation with concurrent nuclear export of cyclin D1 only in MCL cells in which GSK-3beta is under the control of mTOR. These findings suggest that the ability to downregulate cyclin D1 through GSK-3beta may identify subsets of MCL patients who may benefit from the treatment with mTOR inhibitors.

Two very similar studies show the complexity of the genetic changes in mantle cell lymphoma (MCL). Both Schraders et al. and Bea et al. performed combined genomic and expression profiling. Schraders et al. [13] used a restricted group of classical mantle cell lymphomas, whereas Bea et al. [14] used both cell lines and tumors with different morphologies. Not unexpectedly, this approach resulted in higher percentages of specific changes in the Schraders study, pointing to mitochondrial metabolism, DNA repair, and chromosomal stability, whereas the Bea paper indicates a great variation of genes in many pathways, but often affected in only a minority of the cases. In a more direct approach, Gelebart et al. [15] investigated the Wnt pathway in MCL and found it affected in both cell lines (three out of three) and tumor samples (33 out of 46).

A very different approach for treating MCL patients might be immunotherapy directed against cyclinD1; this might be possible since Kondo et al. [16] found in the blood of MCL patients cytotoxic T cells directed against the cyclinD1 positive MCL-cells.

Espinosa et al. [17] studied the NF-kappaB signaling pathway in diffuse large B-cell lymphoma (DLBL) using immunohistochemistry for the involved proteins. They were able to show that NF-kappaB activation is seen in a minority of cases, that it is generally mediated through the classical pathway, not associated with the activated B- or germinal center type and that it predicts good prognosis.

Uddin et al. [18] studied S-phase kinase protein 2 (SKP2), an F-box protein, that targets cycle-dependent kinase inhibitor p27KiP1 via ubiquitin-mediated degradation. Using a large number of tissue samples from DLBL and cell lines, they showed that about $40 \%$ of the DLBL expressed SKP2, which was inversely related to p27Kip1 expression. Treatment of the cell lines with bortezomib resulted in downregulation of SKP2 and increased expression of p27Kip1 resulting in increased apoptosis.

Deregulated Myc results in aggressive lymphomas. Mason et al. [19] investigated in a mouse model the efficacy of ABT-737, a small molecule that mimics antagonists of bcl-2 proteins. This drug was effective in double hit tumors (bcl2 and myc translocation), but not in myc lymphomas only.

\section{T-cell lymphoma}

The knowledge on the biology of T-cell lymphomas is less than that of B-cell lymphomas, due to the fact that these tumors are rarer, but also due to the larger complexity of the T-cell system compared to the B cells. The importance of the WNT signaling pathway in lymphocyte development and in many forms of cancer prompted Groen et al. [20] to 
investigate the nuclear expression of beta-catenin in a large panel of lymphomas $(n=162)$. In contrast to Gelebart (see above), they did not find MCL affected, but found nuclear expression mainly in precursor T-cell malignancy (nine out of 27) and a few mature T-cell lymphomas, and they showed gain of function mutation in the gene in a few of them. In the majority of lesions, however, the WNT pathway was still functional and thus a potential target for therapy.

Anaplastic large-cell lymphoma (ALCL) is relatively well understood, since it has often a translocation involving the ALK gene. The remarkable morphology of the cells now seems to be due to the function of the NPM-ALK fusion gene. Ambrogio et al. [21] showed that the kinase activity of the nucleophosmin (NPM)-ALK fusion regulated the shape of ALCL cells. NPM-ALK formed a complex with the guanine exchange factor VAV1, enhancing its activation through phosphorylation. VAV1 increased Cdc42 activity, and in turn, $\mathrm{Cdc} 42$ regulated the shape and migration of ALCL cells.

Marzec et al. [22] report that the NPM/ALK-carrying Tcell lymphoma cells strongly express the immunosuppressive cell-surface protein CD274, as determined on the mRNA and protein level. Using the small molecule ALK inhibitor CEP-14083, they were able to inhibit NPM/ALK function resulting in the downregulation of CD274 expression. These findings identify an additional cell-transforming property of NPM/ALK and describe a direct link between an oncoprotein and an immunosuppressive cell-surface protein.

The proteasome inhibitor bortezomib is now extensively studied, since it has the potential of being active in many forms of cancer. Shen et al. [23] had found earlier that it is effective in NK-cell neoplasms, and now report that it is effective in some cell lines at the same doses that is used for multiple myeloma inducing mitochondrial apoptosis, whereas in one cell line, a higher concentration was needed, after which mitotic catastrophe occurred. In the same tumor type, that is invariable carrying the Epstein-Bar Virus (EBV), Ian et al. [24] were able to inhibit proliferation by silencing the EBNA1 gene of the virus.

\section{Epidemiology of lymphoma}

Even though there is an improving survival for many forms of cancer, history of medicine tells us that the discovery of the cause of a disease is of great importance for the final solution. Etiological studies in cancer are relatively limited, and until now, epidemiological studies on risk factors did use lymphomas as a broad category. Now we know that lymphomas form a series of different disease entities, and thus, studies into risk factors should separate the different forms of lymphoma. Morton et al. [25] did such an analysis on the more common types, DLBL (although this is likely not a single entity), follicular lymphoma (FL), marginal zone lymphoma (MZL), and CLL. They found that late birth order and high body mass index $\left(\geq 35 \mathrm{~kg} / \mathrm{m}^{2}\right)$ increased risk for DLBCL alone. Autoimmune conditions increased risk for marginal zone lymphoma alone. The tumor necrosis factor G-308A polymorphism increased risks for both DLBCL and marginal zone lymphoma. Exposure to certain dietary heterocyclic amines from meat consumption increased risk for CLL/SLL alone. There were no significant risk factors for follicular lymphoma alone. These data indicate clearly that such studies need to focus on separate disease entities.

The association of Chlamydia psittaci (CP) with ocular marginal zone lymphoma is well known. Ponzoni et al. [26] investigated in 205 extraorbital lymphomas and 135 nonneoplastic controls the presence of CP by multiple methods. CP DNA was equally prevalent in nonocular nodal and extranodal lymphomas: among the latter, it was more common in diffuse large B-cell lymphomas of the skin $(P=$ 0.03 ) and Waldeyer's ring. This important study sheds new light on the causative role of this microorganism in the development of lymphomas.

Improving outcome for lymphoma patients is well described in clinical studies, but those studies include always a selection of patients. It is therefore important to study outcome on a population basis. Al-Tourah et al. [27] investigated the data from the population-based registry of British Colombia (Canada) and analyzed 600 patients with newly diagnosed FL. With a median follow-up of 109 months, 170 (28\%) developed transformation, 107 (63\%) of them based on biopsy confirmation, the others on clinical parameters. The annual risk of transformation was $3 \%$ continuously through 15 years. A multivariate analysis of clinical factors at diagnosis identified advanced stage as the only predictor of future transformation. The median post-transformation survival was 1.7 years. The 5-year survival was superior for patients with limited extent transformation compared with those with advanced cases (66\% vs $19 \%, P<.0001)$. Clinically diagnosed transformation has an equal impact on outcome as biopsy proven transformation.

Many studies are available that describe specific features of certain lymphoma types in several regions of the world. By comparing these, one gets further insight in the background of these lymphoma types, although it is often difficult to understand what the causes of differences are. Nomura et al. [28] describe 21 pediatric high-grade B-cell lymphomas in Papua New Guinea and found a frequent association with EBV, regardless of subtype, and even in lymphoblastic lymphoma (LBL). A large series of endemic Burkitt lymphomas (BL) was described from Uganda by 
Ogwang et al. [29]. Among 500 patients, median age was 6 years and male-to-female ratio was 1.8:1. The agestandardized incidence was 2.4 per 100,000 , being 0.6 in $1-$ 4 year olds, 4.1 in 5-9 year olds and 2.8 in 10-14 year olds. Most children presented with abdominal (56\%, M/F 1.4:1) vs. only facial tumors $(35 \%, \mathrm{M} / \mathrm{F} 3.0: 1)$. Abdominal tumors occurred in a little older (mean age: 7.0 vs. 6.0 years) and more frequently in female children (68\% vs. 50\%). A study on $234 \mathrm{BL}$ cases from Brazil by Queiroga et al. [30] revealed that $\mathrm{EBV}$ was present in $53 \%$ of all $\mathrm{BL}$ cases, varying from $29 \%$ (12 out of 42 ) in the South to $76 \%$ (13 out of 17) in the North. The frequency was higher in the pediatric group. Expression of p53 protein was observed in $16 \%$, and only rare cases showed p63 expression. They conclude that $\mathrm{BL}$ in Brazil is regionally distinct and has a low incidence of p53 overexpression and a higher-thanexpected association with EBV in sporadic cases.

From Argentina, a series of 40 extranodal oral lymphomas was reported by Keszler et al. [31]. Overall mean age of patients was 49 years, and frequency was greater in males. The most common location was the gingiva, followed by the palate. Intraosseous cases were more frequent in mandible (75\%) than in upper maxilla. Of the cases, $100 \%$ were B-cell lymphomas, with a high frequency of BLBL. Only $60 \%$ of the plasmablastic lymphomas in the series came from $\mathrm{HIV}+$ patients.

Paul et al. [32] describe 56 cases of primary central nervous system lymphomas from India out of a 19-year study period. These lymphomas comprised $1 \%$ of all intracranial neoplasms. The patients ranged from 10 to 75 years of age with a median age of 42 years, which is relatively young. Only one patient was HIV positive. All cases were diffuse large B-cell lymphomas on histopathology except for a single case of CD 3-positive T-cell lymphoma.

\section{Defining entities}

\section{Hodgkin lymphoma}

Our understanding of Hodgkin lymphoma has increased largely but is by far not complete. Using the new insights, one might forget earlier findings. Benharroch et al. [33] reviewed their 201 cases of cHL and used strict criteria for subclassification by which they detected 12 cases of lymphocyte-depletion. These cases were often EBV positive and also CD15, although the latter was important in the original diagnosis. To increase the understanding of the relatively rare nodular lymphocyte predominant HL, Brune et al. [34] performed expression array analysis on microdissected L\&H cells and compared the results to those of normal B cells and B cells from other lymphoma types.
There was a very high similarity to the tumor cells from Tcell-rich B-cell lymphoma as well as cHL, with partial loss of B-cell phenotype and altered expression of many genes involved in cancerogenesis.

\section{B-cell lymphomas}

Most follicular lymphomas (FL) present in lymph nodes, but extranodal presentation may occur. Weinberg et al. [35] compared 27 extranodal FL to 44 nodal cases, and in addition, eight cutaneous follicle center cell lymphomas, known to be a different entity. Extranodal cases were more often diffuse, lacked CD10 expression and had, surprisingly, more often $t(14 ; 18)$, especially the minor breakpoint. Follow-up was quite similar between the groups. This paper points to the difficulty of the use of many criteria (clinical, morphological, phenotypical, genetic) to make a diagnosis, and then use the same criteria as prognosticator or as single criterium.

Two studies deal with ocular/orbital lymphomas, Lagoo et al. [36] focusing on pathological features, Sjo et al. [37] on more clinical aspects. This relatively rare lymphoma is not always easy to diagnose and classify, since it often has not the typical features of MZL compared to gastric cases. Only a minority of the cases has a translocation that involves the MLT gene (15\% in the USA study, $5 \%$ in the Danish study). About $25 \%$ of the patients have disseminated disease, and 5-year survival is about $75 \%$.

Takino et al. [38] collected cutaneous MZL from Asia, Germany, and the USA; in total, 60 cases and showed that they have fairly common clinical and pathologic features. In nine out of 25 Asian cases, there was tissue eosinophilia, which was virtually absent in the Western cases. In no case was Borrelia or the MALT1-API2 fusion found.

Quite some work is done on the detection of a molecular marker for MZL. It is already well known that several translocations leading to NFkappaB activation occur in extranodal MZL. Vinatzer et al. [39] studied 29 cases from different sites with several cytogenetic methods and document the following: balanced translocations were found in 21 cases. IGH was rearranged in the majority of cases with balanced translocations $(n=17 / 21)$; three cases had $t(11 ; 18) /$ API2-MALT1, and one case had novel $t(6 ; 7)$ (q25;q11), respectively. IGH partner genes involved MALT1, FOXP1, BCL6, and four new chromosomal regions on chromosome arms $1 p, 1 q, 5 q$, and 9p. LDIPCR identified three novel partner genes on $1 p$ (CNN3), $5 q$ (ODZ2), and 9p (JMJD2C). FISH assays were established and confirmed LDI-PCR results. QRT-PCR showed deregulation of the novel genes in the translocation-positive cases. These findings underline the molecular heterogeneity of MZL and also demonstrate that presently molecular 
classification is not possible. Sinn et al. [40] focused on colorectal and gastric cases and found MLT translocation in two out of nine cases and CpGisland methylation (CIMP) eight out of 13 cases. The CIMP-positive cases had a poorer survival. Chanudet et al. [41] used high-resolution chromosome 6 tile-path array-CGH which identified NFkappaB inhibitor $\mathrm{A} 20$ as the target of $6 \mathrm{q} 23.3$ deletion and TNFA/B/C locus as a putative target of 6p21.2-22.1 gain. Interphase fluorescence in situ hybridization (FISH) showed that A20 deletion occurred in MALT lymphoma of the ocular adnexa $(8 / 42=19 \%)$, salivary gland $(2 / 24=$ $8 \%)$, thyroid $(1 / 9=11 \%)$, and liver $(1 / 2)$, but not in the lung [26], stomach [45], and skin [13]. A20 deletion and TNFA/ $\mathrm{B} / \mathrm{C}$ gain were significantly associated and exclusively found in cases without characteristic translocation. In ocular cases, A20 deletion was associated with concurrent involvement of different adnexal tissues or extraocular sites at diagnosis, a higher proportion of relapse (67\% versus $37 \%)$, and a shorter relapse-free survival.

Lymphoplasmacytic lymphoma (LPL) is difficult to separate from MZL. Sargent et al. [42] studied 17 nodal LPL which were divided into classic $(n=5)$, vaguely nodular $(n=5)$, and others $(n=7)$. They were able to show that among the classic LPL, four out of four had an IgM paraproteinemia, five out of five had bone marrow involvement $(\mathrm{BM}+)$, and one out of five had +MALT1. One of one vaguely nodular LPL had an IgM paraprotein, two out of four were $\operatorname{IgM}+$, two out of four $\operatorname{IgG}+$, one out of three had $\mathrm{BM}+$, and one out of five had an $\operatorname{IgH}$ rearrangement. Among the other cases, two out of three had a paraprotein, two out of seven were $\operatorname{IgM}+$, five out of seven $\mathrm{IgG}+$, and zero out of three had $\mathrm{BM}+$. Of these cases, one showed +12 , one +18 , and one IgH/BCL2 translocation plus +18 . None of the 17 cases had a $6 \mathrm{q} 21$ deletion or +3 . These results are quite different from those obtained generally in MZL, but the genetic data differ also from those seen in bone marrow-derived LPL.

Although FL is characterized by $t(14 ; 18)$, not all cases carry the translocation. Gaqyi et al. [43] collected bcl-2 negative (translocation and protein) FL and studied the mutational status of the $\operatorname{IgH}$ gene, but did not find differences compared to bcl2-positive cases. Additional genetic alterations are common in FL. d'Amore et al. [44] found in $t(14 ; 18)$ positive cases in initial and follow-up biopsies of 360 patients +7 , del(6q), $+\operatorname{der}(18) t(14 ; 18),+18$, and $+X$ as the common alterations, multiple clones were common, and genetic divergence was found especially in follow-up biopsies.

Since MUM1 is overexpressed in the activated type of DLBL, Hunt et al. [45] investigated whether MUM1 is translocated in these tumors. In one out of 16 cases, a MUM1 break was detected, and none of 17 germinal center-type DLBL carried the break.
Burkitt lymphoma (BL) is defined by morphology, phenotype, and MYC translocation, but Leucci et al. [46] describe in a series of bona fide endemic (African) BL that five out of 35 cases did not have a break in the MYC gene that could be detected by a split signal probe covering the gene, and using fusion probes, no juxtaposition to immunoglobulin genes was detected either. In these cases, the miRNA hsa-mir-34b was downregulated, and in in vivo studies this miRNA could regulate MYC expression, providing an alternative pathway in MYC-negative BL. Such cases were not included in the expression and CGH array studies by Salivierra et al. [47]. In the array study, it was shown that pediatric and adult cases of Burkitt lymphoma have similar genetic alterations but that DLBL that are similar to BL using expression array have different genetic backgrounds. These data confirm that expression arraying is not a tool to be used in the classification of tumors.

\section{T-cell lymphomas}

Regulatory $\mathrm{T}$ cells are a relatively recent recognized subset of T-lymphocytes, expressing FoxP3 (although not exclusively). Bonzheim et al. [48] investigated whether subtypes of T-cell lymphomas were derived from these cells but detected among anaplastic large cell lymphomas (ALCL), angioimmunoblastic T-cell lymphomas (AILD), and peripheral T-cell lymphomas (PTCL) only one such case, which was rapidly progressive.

T-cell lymphomas are molecularly less characterized compared to B-cell lymphomas. Feldman [49] performed an important study in which the multiple myeloma oncogene-1/interferon regulatory factor-4 (IRF4) locus was analyzed by FISH. IRF4 translocations are known to exist in myeloma and some B-cell lymphomas, but were not yet studied in PTCLs. Among 169 PTCLs, 12 cases had IRF4 translocations. Two cases with $t(6 ; 14)$ (p25;q11.2) had translocations between IRF4 and the T-cell receptoralpha (TCRA) locus. Both were cytotoxic PTCLs, involving bone marrow and skin. Eight of the remaining ten cases were cutaneous anaplastic large-cell lymphomas (ALCLs) without TCRA rearrangements $(57 \%$ of cutaneous ALCLs tested). These findings demonstrate that IRF4 translocations are a recurrent genetic abnormality in PTCLs. Cytotoxic PTCLs involving bone marrow and skin and containing IRF4/TCRA translocations might even represent a distinct clinicopathologic entity.

A key feature of enteropathy-associated T-cell lymphoma is the loss of surface CD3 with remaining cytoplasmic expression. Using a cell line derived from such a lymphoma, Tjon et al. [50] were able to determine the mechanism responsible for this: defective assembly or 
association of T-cell receptor chains. The finding was confirmed in two other patients.

ALCL is defined by CD30 expression and morphological features, but the latter may be misleading in some cases. Bovio and Allen [51] determined by flow cytometry the expression profile of 20 ALCL, nine ALK1 positive, 11 negative. Almost all cases expressed at least one T-cellassociated antigen. CD13 and CD33 were expressed in all ALK1 positive cases, but in only 1 Alk1 negative case. Misinterpretetion for myeloid sarcoma should be avoided in the positive cases.

Kong et al. [52] did an extensive analysis of 22 Asian cases of subcutaneous panniculitis-like T-cell lymphoma. Unusual features were found in two cases, namely, CD8 negative. CD30 was negative in all cases, and CD56 was focally positive in two cases. EBV was present in one case. All cases were clonal using the Biomed 2 primer sets. Cases with angioinvasion were more aggressive.

The immunophenotype of 84 cases of nasal-type extranodal NK/T cell lymphoma was studied using TMA's by Schwartz et al. [53]. CD2 was positive in $93 \%$, CD3 in $84 \%$, CD5 in $27 \%$, CD56 in $58 \%$, granzyme in $71 \%$, perforin in $86 \%$, TIA1 in $90 \%$, CD30 in $35 \%$, and $\mathrm{EBV}$ in $87 \%$; CD20 was absent in all cases.

\section{Cutaneous lymphomas}

Cutaneous lymphomas remain an extensively studied group, especially compared to its relatively rarety. RiouGotta et al. [54] described 71 cases from a population-based registry in France, covering the period from 1980 to 2003. Of the cases, $82 \%$ were of T-cell origin (the majority mycosis fungoides; MF), and thus, $18 \%$ were B-cell lymphomas. There was an increase in incidence from 0.2 to $0.7 / 100.000$ and 5 year survival was about $65 \%$ for MF and also for the other types taken together.

Van Maldegem [55] underlined that cutaneous lymphomas are different from lymphomas from other sites, also molecularly. They studied an extensive panel of primary cutaneous MZLs and show that these are different compared to other extranodal MZL. Whereas most noncutaneous MZLs express IgM, cutaneous MZLs in majority express IgG, IgA, and IgE. Furthermore, these isotypeswitched cases lack CXCR3 and seem to arise in a different inflammatory environment.

Granulomatous slack skin disease (GSS) and granulomatous MF are rare and puzzling. Kempf et al. [56] collected four cases of the former and 15 of the latter. These cases were diagnosed according to the WHO classification. There was little epidermotropism, and treatment was not successful in most cases, and one third of the patients died of their disease. Why granulomas occur remains unknown.

\section{New entities/subtypes}

Like many immunodeficiencies is the Nijmegen breakage syndrome associated with lymphoproliferations. Gladkowska-Dura et al. [57] described their experience from 105 such patients, of whom half developed a lymphoproliferation. From 14 patients, the pathology is described. Most commonly, DLBL and T-LBL/ALL were present, and all had a clonal disease. Using split signal probes breaks in Ig and TCR genes were commonly detected, indicating that the repair defect is indeed responsible for the development of lymphoproliferations.

The description of the pathology in IgG4 disease becomes extensive. Sato et al. [58] collected experience on ocular lesions from 21 patients. In 17 of them, the lacrimal gland was involved, the conjunctiva in no patient. There was a dense, fibrotic plasmacellular infiltrate with IgG4 expression. In two out of 17, the proliferation was clonal.

The subtyping of DLBL is of continuous interest. Lenz et al. [59] performed an analyses of 203 cases combining expression and CGH array. They were able to show that the three subgroups, germinal center B-cell-like (GCB), activated $\mathrm{B}$-cell-like $(\mathrm{ABC})$, and primary mediastinal (PMB) had different patterns of genomic changes, but no specific alterations were found. INK4a/ARF was commonly deleted, and FoxP1 upregulated in the ABC group. In the GBC group, amplification of mir-17-92 and deletion of PTEN were often seen.

Wong et al. [60] analyzed 32 DLBL of the upper aerodigestive tract using immunohistochemistry and found a similar distribution for $\mathrm{ABC}$ and $\mathrm{GBC}$ cases compared to other sites and EBV in only one patient. They conclude that DLBL from this site is not a specific entity.

Dunphy et al. [61] detected a case of PMB with $t(14 ; 18)$ and analyzed 24 cases in detail using FISH, PCR, and immunohistochemistry. Four of the cases had features that are associated with germinal center origin, and these might form a subset of this entity.

The role of EBV in lymphoproliferations in immunedeficient patients is well known. Increasingly, EBV is being recognized in lymphomas from patients with no clear immune deficiency, especially in the elderly. Kleinschmidt et al. [62] describe four patients with central nervous system lymphomas that were on imaging suggestive for EBV-associated cases and who had been treated with a variety of immune suppressive drugs. Since the association is not well known, and pathologists are not always well informed, the authors suggest that EBV testing should be done more often.

Ketzenberger et al. [63] described a series of $35 \mathrm{FL}$ with predominantly diffuse growth pattern. Almost all of the cases lacked the $t(14 ; 18)$ but had a typical immunopheno- 
type (CD10, bcl6, and CD23 expression). The expression profile of four of the cases was studied and comparable with more classic FL. The patients had often low-stage disease and 27 out of 29 cases had a 1p36 deletion, all in all suggesting that this may represent a separate (sub)entity.

The testis and the central nervous system are considered as immune-privileged sites, and DLBL arising in these sites (IP-DLBL) have some special features. Booman et al. [64] performed a gene expression and CGH-array study on 15 central nervous system (CNS) cases, nine testicular cases, and 15 nodal DLBL, which revealed that loss of 6p21.32p25.3, including the HLA genes was associated with both types of IP-DLBCL, whereas gain of 2p16.1-p25.3 was associated with nodal DLBCL. Gain of 12q15-q21.1 and 12q24.32-q24.33 was associated with CNS DLBCL and gain of 19q13.12-q13.43 with testicular DLBCL. Analysis of candidate genes in site-specific regions and minimal common regions revealed two major groups of genes: one involved in the immune response, including regulation of HLA expression, and the other involved in apoptosis, including the p53 pathway. The presence of both shared and site-specific aberrations in CNS and testicular DLBCLs underlines the concept of IP-DLBCL but also indicates that IP-DLBCLs of the CNS and testis do not form a single entity.

DLBL from extranodal sites have generally a better outcome than nodal cases. This was confirmed by Sato et al. [65] who studies oral cases (excluding tonsillar ones), even though 17 out of 21 cases were of $\mathrm{ABC}$ type as determined by immunohistochemistry.

A recently described lesions is atypical lymphocytic panniculitis (ALLP). Magro et al. [66] describe seven such patients who have waxing and waning placques. Since a continuum with subcutaneous panniculits like T-cell lymphoma had been suggested, they performed clonality testing, and all lesions were clonal, and the clones detected were preserved in follow-up biopsies. This situation, very similar to refractory celiac disease, and also monoclonal gammopathy of undetermined significance points to the importance of interpretation of clonality testing in the complete clinicopathologic setting.

Akiyama et al. [67] describe five cases of CD8+, CD56+ T-cell lymphoma in the small intestine, while the patients lack enteropathy. There was no EBV, and the TCR was clonally rearranged, and the clinical course was dismal. These tumors seem closely related to EATL.

After seeing two cases of ALCL in the breast of women who had silicone implants, de Jong et al. [68] performed a national case-control study in the Netherlands. In 16 years 11 primary ALCL in the breast had been diagnosed, and five of these were in women with implants. In women with other primary breast lymphomas, only one had an implant. These data suggest that breast implants have a small but significant risk for developing ALCL. Another unusual presentation of ALCL was discovered by Mosunjac et al. [69] who analyzed five autopsy-detected ALCL cases. These patients had had a rapid clinical problem that was reminiscent of sepsis or fever of unknown origin and lacked lymphadenopathy. These cases had extranodal involvement and often hemophagocytosis.

Rodriquez-Pinilla et al. [70] collected 146 cases of T-cell lymphoma to investigate the cell of origin. First, they looked for PD-1-positive cases which were classified as AILT, known to be derived from follicular helper T cells. The other cases were studied by TMA using a wide panel of markers and EBV; of the non-AILT cases almost 30\% expressed PD-1 as well and many of these expressed other follicular helper T-cell markers also (CXCL13, bcl6, CD10). The authors suggest that the spectrum of AILT may be wider than previously thought but also that other types of $\mathrm{T}$-cell lymphoma may be derived from follicular $\mathrm{T}$ cells.

\section{Pitfalls in lymphoma diagnosis}

Pathologists recognize that lymphoma classification requires special expertise. LaCasce et al. [71] investigated whether the WHO-classification has facilitated the correct diagnosis of lymphomas by evaluating the results from their referred cases. For this analysis they focused on the five most common entities and found that the discordancy rate was $6 \%$, with the most discordancies due to grading FL. The majority of discordant cases $(80 \%)$ might have had a different treatment. Since less common lymphomas total generally up to about $20-25 \%$ of all cases, this study favors review of lymphoma even in this era of WHO classification and many ancillary techniques.

Castleman's disease remains an enigmatic lesion with a variable morphology. Based on 11 cases, Kojima et al. [72] describe the different types of follicles one may encounter in Castleman's disease and delineate the sometimes difficult differential diagnosis with reactive lesions on the one side, and HL on the other.

Cancer cells do not behave like normal cells and therefore unusual expression of markers can occur. Wang et al. [73] report four cases of CD-3 positive B-cell lymphomas and Rahemtullah et al. [74] nine cases of CD20-positive T-cell lymphomas, stressing the need for double positive and negative markers for lineage determination in malignant lymphoproliferations.

\section{Prognostic factors in lymphoma}

Investigations into prognostic factors remain popular. Quite a series of papers on this topic were published, and only a 
small sample of results is given. None of the studies were confirmatory in nature, and those are the only ones in which clinical application can be found. Schreck et al. [75] demonstrate that a large number of Th2 cells in HL is related to better survival; Dong et al. [76] show that bcl10 expression (next to $t(11 ; 14)$ ) is related to HP-eradication unresponsiveness; according to Wang et al. [77], cytoplasmic sox11-expressing MCLs have a poorer survival; mutation nor polymorphism of the CD20 gene is predicting rituximab response (Sar et al. [78]); Aktas et al. [79] show that high apoptotic index is related to good prognosis in pediatric lymphomas; Lenz et al. [80] describes new gene signatures that predict therapy response in DLBL; Peh et al. [81] found that bcl-6 expression is associated with poor survival in DLBL and immunohistochemically determined ABC not; according to Johnson et al. [82], DLBL with low CD20 expression have lower survival rate; Ki67 and Pim1 are independent indicators of poor survival in MCL (Hsi et al. [83]); low Ki67 is a negative predictor of survival in DLBL (Hasselblom et al. [84]); SIRT1 expression is associated with poor prognosis in DLBL (Jang et al. [85]); in FL, Johnson et al. [86] show that secondary genetic alterations indicate aggressive behavior; Hasselblom et al. [87] show that the number of CD68-positive cells in DLBL does not predict prognosis; TCL1A is associated with more aggressive clinical behavior in CLL and MCL according to Aggarwal et al. [88]; aberrations in the MYC locus are associated with poor outcome in DLBL (Klapper et al. [89] and Yoon et al. [90]); expression of P-glycoprotein indicates therapy unresponsiveness in nasal type NK/T cell lymphoma according to Wang et al. [91];

\section{Ancilliary techniques}

Flow cytometry is increasingly used for the phenotyping of lymphomas, but $\mathrm{HL}$ is often difficult to recognize due to the scarcity of tumor cells. In a large study using flow cytometry of $76 \mathrm{HL}$ and 156 reactive lymph nodes, Seegmiller et al. [92] showed that HL can be suggested by the presence of many CD7- and CD4-positive cells. Using the same technique, Pierson et al. [93] show that aberrant CD26 expression indicates, together with other Tcells markers, T-cell lymphoma, but it is not specific.

FISH is now commonly used for the detection of aberrations in specific genes. De Rijk et al. [94] describe a robust paraffin tissue approach using split signal probes, tested in eight different laboratories using 16 different probes covering the most important regions involved in translocation in lymphomas. This method uses tissue sections, so that even small areas of tumor can be evaluated without microdissection. Using isolated nuclei paraffin embedded tissue from 20 cases of CLL, Flanagan et al.
[95] were able to determine almost all aberrations detected in blood samples. Huh et al. [96] used this method for staging on bone marrow aspirates and showed that FISH is more sensitive than classic cytogenetics, but no correlation with immunohistochemistry was done.

Clonality testing is nowadays an important tool in the management of lymph node biopsies, but is prone to mistakes. Groenen et al. [97] use a case-based approach to describe common pitfalls in the interpretation of TCR clonality testing and reiterate the importance of interpretation of the molecular results in the context of the histological and immunohistochemical findings.

Santon et al. [98] performed clonality testing on gastric biopsies from 19 patients treated for gastric MZL and found persistent clonality even though histology did not show lymphoma anymore. This was especially the case in tumors with $t(11 ; 14)$. The clinical meaning of this finding is not yet clear.

Morales et al. [99] tackle the difficult problem of separating reactive $(n=23)$ form malignant $(n=26)$ B-cell proliferations in the skin, using the Biomed set of primers. In patients with a lymphoma, a clone was detected in $85 \%$ of the samples, and in only $4 \%$ of the reactive infiltrate was the data very promising.

Tan et al. [100] analyzed the occurrence of B-cell clonality in 74 T-cell lymphomas. Using the Biomed approach, $86 \%$ had a clonal TCR, and $8 \%$ a concurrent clonal B-cell rearrangement. There was no association with the presence of EBV.

Cytology obtained from fine needle aspirates (FNA) is a limited invasive option for diagnosing lymphomas but has limitations. Pai et al. [101] used FNA-obtained cells for morphology, phenotyping, and molecular tests to evaluate enlarged lymph nodes in patients with mycosis fungoides. In seven out of ten patients, they could determine the presence of tumor cells in the lymph node; three of them had large-cell transformation. Remarkably, two of the patients had HL in the lymph node. This study shows possibilities of FNA in an experienced setting.

Also, multicolor FISH is possible on FNA material as shown by Caraway et al. [102]. In 49 out of 50 patients with CLL, they were able to obtain data on genetic aberrations, with similar prognostic impact as known from traditional studies.

\section{References}

1. Chetaille B, Bertucci F, Finetti P, Esterni B, Stamatoullas A, Picquenot JM, Copin MC, Morschhauser F, Casasnovas O, Petrella T, Molina T, Vekhoff A, Feugier P, Bouabdallah R, Birnbaum D, Olive D, Xerri L (2009) Molecular profiling of classical Hodgkin's lymphoma tissues uncovers variations in the 
tumor microenvironment and correlations with EBV infection and outcome. Blood (in press)

2. Asano N, Yamamoto K, Tamaru JI, Oyama T, Ishida F, Ohshima K, Yoshino T,Nakamura N, Mori S, Yoshie O, Shimoyama Y, Morishima Y, Kinoshita T, Nakamura S (2009) Age-related EBV-associated B-cell lymphoproliferative disorders: comparison with EBV-positive classical Hodgkin lymphoma in elderly patients. Blood (in press)

3. de Jong D, Koster A, Hagenbeek A, Raemaekers J, Veldhuizen D, Heisterkamp S, de Boer JP, van Glabbeke M (2009) Impact of the tumor microenvironment on prognosis in follicular lymphoma is dependent on specific treatment protocols. Haematologica 94(1):70-77

4. van Krieken JH (2008) New developments in the pathology of malignant lymphoma: a review of the literature published from May to July 2008. J Hematopathol 1:145-160

5. Ai WZ, Hou JZ, Zeiser R, Czerwinski D, Negrin RS, Levy R (2009) Follicular lymphoma B cells induce the conversion of conventional CD4+ T cells to T-regulatory cells. Int J Cancer 124 (1):239-244

6. Chadburn A, Hyjek EM, Tam W, Liu Y, Rengifo T, Cesarman E, Knowles DM (2008) Immunophenotypic analysis of the Kaposi sarcoma herpesvirus (KSHV; HHV-8)-infected B cells in HIV+ multicentric Castleman disease (MCD). Histopathology 53 (5):513-524

7. Mack AA, Sugden B (2008) EBV is necessary for proliferation of dually infected primary effusion lymphoma cells. Cancer Res 68:6963-6968

8. Everton KL, Abbott DR, Crockett DK, Elenitoba-Johnson KS, Lim MS (2009) Quantitative proteomic analysis of follicular lymphoma cells in response to rituximab. J Chromatogr B Analyt Technol Biomed Life Sci (in press)

9. Lapalombella R, Yu B, Triantafillou G, Liu Q, Butchar JP, Lozanski G, Ramanunni A, Smith LL, Blum W, Andritsos L, Wang DS, Lehman A, Chen CS, Johnson AJ, Marcucci G, Lee RJ, Lee LJ, Tridandapani S, Muthusamy N, Byrd JC (2008) Lenalidomide down-regulates the CD20 antigen and antagonizes direct and antibody-dependent cellular cytotoxicity of rituximab on primary chronic lymphocytic leukemia cells. Blood 112 (13):5180-5189

10. Jones RJ, Chen Q, Voorhees PM, Young KH, Bruey-Sedano N, Yang D, Orlowski RZ (2008) Inhibition of the p53 E3 ligase HDM-2 induces apoptosis and DNA damage-independent p53 phosphorylation in mantle cell lymphoma. Clin Cancer Res 14 (17):5416-5425

11. Roué G, López-Guerra M, Milpied P, Pérez-Galán P, Villamor N, Montserrat E, Campo E, Colomer D (2008) Bendamustine is effective in p53-deficient B-cell neoplasms and requires oxidative stress and caspase-independent signaling. Clin Cancer Res 14(21):6907-6915

12. Dal Col J, Dolcetti R (2008) GSK-3beta inhibition: at the crossroad between Akt and mTOR constitutive activation to enhance cyclin D1 protein stability in mantle cell lymphoma. Cell Cycle 7(18):2813-2816

13. Schraders M, Jares P, Bea S, Schoenmakers EF, van Krieken JH, Campo E, Groenen PJ (2008) Integrated genomic and expression profiling in mantle cell lymphoma: identification of gene-dosage regulated candidate genes. Br J Haematol 143(2):210-221

14. Bea S, Salaverria I, Armengol L, Pinyol M, Fernandez V, Hartmann EM, Jares P, Amador V, Hernandez L, Navarro A, Ott G, Rosenwald A, Estivill X, Campo E (2009) Uniparental disomies, homozygous deletions, amplifications and target genes in mantle cell lymphoma revealed by integrative high-resolution whole genome profiling. Blood (in press)

15. Gelebart P, Anand M, Armanious H, Peters AC, Dien Bard J, Amin HM, Lai R (2008) Constitutive activation of the Wnt canonical pathway in mantle cell lymphoma. Blood 112 (13):5171-5179

16. Kondo E, Maecker B, Weihrauch MR, Wickenhauser C, Zeng W, Nadler LM, Schultze JL, von Bergwelt-Baildon MS (2008) Cyclin D1-specific cytotoxic T lymphocytes are present in the repertoire of cancer patients: implications for cancer immunotherapy. Clin Cancer Res 14(20):6574-6579

17. Espinosa I, Briones J, Bordes R, Brunet S, Martino R, Sureda A, Sierra J, Prat J (2008) Activation of the NF-kappaB signalling pathway in diffuse large B-cell lymphoma: clinical implications. Histopathology 53(4):441-449

18. Uddin S, Hussain A, Ahmed M, Belgaumi A, Al-Dayel F, Ajarim D, Bavi P, Al-Kuraya KS (2008) S-phase kinase protein 2 is an attractive therapeutic target in a subset of diffuse large Bcell lymphoma. J Pathol 216(4):483-494

19. Mason KD, Vandenberg CJ, Scott CL, Wei AH, Cory S, Huang DC, Roberts AW (2008) In vivo efficacy of the Bcl-2 antagonist ABT-737 against aggressive Myc-driven lymphomas. Proc Natl Acad Sci USA 105(46):17961-17966

20. Groen RW, Oud ME, Schilder-Tol EJ, Overdijk MB, ten Berge D, Nusse R, Spaargaren M, Pals ST (2008) Illegitimate WNT pathway activation by beta-catenin mutation or autocrine stimulation in T-cell malignancies. Cancer Res 68(17):69696977

21. Ambrogio C, Voena C, Manazza AD, Martinengo C, Costa C, Kirchhausen T, Hirsch E, Inghirami G, Chiarle R (2008) The anaplastic lymphoma kinase controls cell shape and growth of anaplastic large cell lymphoma through $\mathrm{Cdc} 42$ activation. Cancer Res 68(21):8899-8907

22. Marzec M, Zhang Q, Goradia A, Raghunath PN, Liu X, Paessler M, Wang HY, Wysocka M, Cheng M, Ruggeri BA, Wasik MA (2008) Oncogenic kinase NPM/ALK induces through STAT3 expression of immunosuppressive protein CD274 (PD-L1, B7-H1). Proc Natl Acad Sci USA 105 (52):20852-20857

23. Shen L, Au WY, Wong KY, Shimizu N, Tsuchiyama J, Kwong YL, Liang RH, Srivastava G (2008) Cell death by bortezomibinduced mitotic catastrophe in natural killer lymphoma cells. Mol Cancer Ther 7(12):3807-3815

24. Ian MX, Lan SZ, Cheng ZF, Dan H, Qiong LH (2008) Suppression of EBNA1 expression inhibits growth of EBVpositive NK/T cell lymphoma cells. Cancer Biol Ther 7 (10):1602-1606

25. Morton LM, Wang SS, Cozen W, Linet MS, Chatterjee N, Davis S, Severson RK, Colt JS, Vasef MA, Rothman N, Blair A, Bernstein L, Cross AJ, De Roos AJ, Engels EA, Hein DW, Hill DA, Kelemen LE, Lim U, Lynch CF, Schenk M, Wacholder S, Ward MH, Hoar Zahm S, Chanock SJ, Cerhan JR, Hartge P (2008) Etiologic heterogeneity among non-Hodgkin lymphoma subtypes. Blood 112(13):5150-5160

26. Ponzoni M, Ferreri AJ, Guidoboni M, Lettini AA, Cangi MG, Pasini E, Sacchi L, Pecciarini L, Grassi S, Dal Cin E, Stefano R, Magnino S, Dolcetti R, Doglioni C (2008) Chlamydia infection and lymphomas: association beyond ocular adnexal lymphomas highlighted by multiple detection methods. Clin Cancer Res 14 (18):5794-5800

27. Al-Tourah AJ, Gill KK, Chhanabhai M, Hoskins PJ, Klasa RJ, Savage KJ, Sehn LH, Shenkier TN, Gascoyne RD, Connors JM (2008) Population-based analysis of incidence and outcome of transformed non-Hodgkin's lymphoma. J Clin Oncol 26 (32):5165-5169

28. Nomura Y, Yoshida S, Karube K, Takeshita M, Hirose S, Nakamura S, Yoshino T, Kikuchi M, Ohshima K (2008) Estimation of the relationship between caspase-3 expression and clinical outcome of Burkitt's and Burkitt-like lymphoma. Cancer Sci 99(8):1564-1569 
29. Ogwang MD, Bhatia K, Biggar RJ, Mbulaiteye SM (2008) Incidence and geographic distribution of endemic Burkitt lymphoma in northern Uganda revisited. Int J Cancer 123 (11):2658-2663

30. Queiroga EM, Gualco G, Weiss LM, Dittmer DP, Araujo I, Klumb CE, Harrington WJ Jr, Bacchi CE (2008) Burkitt lymphoma in Brazil is characterized by geographically distinct clinicopathologic features. Am J Clin Pathol 130(6):946-956

31. Keszler A, Piloni MJ, Paparella ML, Soler Mde D, Ron PC, Narbaitz M (2008) Extranodal oral non-Hodgkin's lymphomas. A retrospective study of 40 cases in Argentina. Acta Odontol Latinoam 21(1):43-48

32. Paul TR, Challa S, Tandon A, Panigrahi MK, Purohit AK (2008) Primary central nervous system lymphomas: Indian experience, and review of literature. Indian J Cancer 45(3):112-118

33. Benharroch D, Levy A, Gopas J, Sacks M (2008) Lymphocytedepleted classic Hodgkin lymphoma-a neglected entity. Virchows Arch 453(6):611-616

34. Brune V, Tiacci E, Pfeil I, Döring C, Eckerle S, van Noesel CJ, Klapper W, Falini B, von Heydebreck A, Metzler D, Bräuninger A, Hansmann ML, Küppers R (2008) Origin and pathogenesis of nodular lymphocyte-predominant Hodgkin lymphoma as revealed by global gene expression analysis. J Exp Med 205 (10):2251-2268

35. Weinberg OK, Ma L, Seo K, Beck AH, Pai RK, Morales A, Kim Y, Sundram U, Tan D, Horning SJ, Hoppe RT, Natkunam Y, Arber DA (2009) Low stage follicular lymphoma: biologic and clinical characterization according to nodal or extranodal primary origin. Am J Surg Pathol (in press)

36. Lagoo AS, Haggerty C, Kim Y, Hammons M, Neufeld K, Redher C, Woodward J, Klintworth GK (2008) Morphologic features of 115 lymphomas of the orbit and ocular adnexa categorized according to the World Health Organization classification: are marginal zone lymphomas in the orbit mucosaassociated lymphoid tissue-type lymphomas. Arch Pathol Lab Med 132(9):1405-1416

37. Sjo LD, Heegaard S, Prause JU, Petersen BL, Pedersen S, Ralfkiaer E (2009) Extranodal marginal zone lymphoma in the ocular region: clinical, immunophenotypical and cytogenetical characteristics. Invest Ophthalmol Vis Sci 50(2):516-522

38. Takino H, Li C, Hu S, Kuo TT, Geissinger E, Muller-Hermelink HK, Kim B, Swerdlow SH, Inagaki H (2008) Primary cutaneous marginal zone B-cell lymphoma: a molecular and clinicopathological study of cases from Asia, Germany, and the United States. Mod Pathol 21(12):1517-1526

39. Sinn DH, Kim YH, Lee EJ, Ko YH, Kim KM (2009) Methylation and API2/MALT1 fusion in colorectal extranodal marginal zone lymphoma. Mod Pathol 22(2):314-320

40. Vinatzer U, Gollinger M, Müllauer L, Raderer M, Chott A, Streubel B (2008) Mucosa-associated lymphoid tissue lymphoma: novel translocations including rearrangements of ODZ2, JMJD2C, and CNN3. Clin Cancer Res 14(20):6426-6431

41. Chanudet E, Ye H, Ferry J, Bacon C, Adam P, Müller-Hermelink H, Radford J, Pileri S, Ichimura K, Collins V, Hamoudi R, Nicholson A, Wotherspoon A, Isaacson P, Du M (2009) A20 deletion is associated with copy number gain at the TNFA/B/C locus and occurs preferentially in translocation-negative MALT lymphoma of the ocular adnexa and salivary glands. J Pathol 217 (3):420-430

42. Sargent RL, Cook JR, Aguilera NI, Surti U, Abbondanzo SL, Gollin SM, Swerdlow SH (2008) Fluorescence immunophenotypic and interphase cytogenetic characterization of nodal lymphoplasmacytic lymphoma. Am J Surg Pathol 32(11):16431653

43. Gagyi E, Balogh Z, Bödör C, Timár B, Reiniger L, Deák L, Csomor J, Csernus B, Szepesi A, Matolcsy A (2008) Somatic hypermutation of IGVH genes and aberrant somatic hypermutation in follicular lymphoma without BCL-2 gene rearrangement and expression. Haematologica 93(12):1822-1828

44. Hunt KE, Hall B, Reichard KK (2009) Translocations involving MUM1 are rare in diffuse large B-cell lymphoma. Appl Immunohistochem Mol Morphol (in press)

45. d'Amore F, Chan E, Iqbal J, Geng H, Young K, Xiao L, Hess MM, Sanger WG, Smith L, Wiuf C, Hagberg O, Fu K, Chan WC, Dave BJ (2008) Clonal evolution in $\mathrm{t}(14 ; 18)$-positive follicular lymphoma, evidence for multiple common pathways, and frequent parallel clonal evolution. Clin Cancer Res 14 (22):7180-7187

46. Leucci E, Cocco M, Onnis A, De Falco G, van Cleef P, Bellan C, van Rijk A, Nyagol J, Byakika B, Lazzi S, Tosi P, van Krieken H, Leoncini L (2008) MYC translocationnegative classical Burkitt lymphoma cases: an alternative pathogenetic mechanism involving miRNA deregulation. J Pathol 216(4):440-450

47. Salaverria I, Zettl A, Beà S, Hartmann EM, Dave SS, Wright GW, Boerma EJ, Kluin PM, Ott G, Chan WC, Weisenburger DD, Lopez-Guillermo A, Gascoyne RD, Delabie J, Rimsza LM, Braziel RM, Jaffe ES, Staudt LM, Müller-Hermelink HK, Campo E, Rosenwald A (2008) Leukemia and Lymphoma Molecular Profiling Project (LLMPP). Chromosomal alterations detected by comparative genomic hybridization in subgroups of gene expression-defined Burkitt's lymphoma. Haematologica 93 (9):1327-1334

48. Bonzheim I, Geissinger E, Tinguely M, Roth S, Grieb T, Reimer P, Wilhelm M, Rosenwald A, Müller-Hermelink HK, Rüdiger T (2008) Evaluation of FoxP3 expression in peripheral T-cell lymphoma. Am J Clin Pathol 130(4):613-619

49. Feldman AL, Law M, Remstein ED, Macon WR, Erickson LA, Grogg KL, Kurtin PJ, Dogan A (2009) Recurrent translocations involving the IRF4 oncogene locus in peripheral T-cell lymphomas. Leukemia (in press)

50. Tjon JM, Verbeek WH, Kooy-Winkelaar YM, Nguyen BH, van der Slik AR, Thompson A, Heemskerk MH, Schreurs MW, Dekking LH, Mulder CJ, van Bergen J, Koning F (2008) Defective synthesis or association of T-cell receptor chains underlies loss of surface T-cell receptor-CD3 expression in enteropathy-associated T-cell lymphoma. Blood 112(13):510310

51. Bovio IM, Allan RW (2008) The expression of myeloid antigens $\mathrm{CD} 13$ and/or CD33 is a marker of ALK+ anaplastic large cell lymphomas. Am J Clin Pathol 130(4):628-634

52. Kong YY, Dai B, Kong JC, Zhou XY, Lu HF, Shen L, Du X, Shi DR (2008) Subcutaneous panniculitis-like T-cell lymphoma: a clinicopathologic, immunophenotypic, and molecular study of 22 Asian cases according to WHO-EORTC classification. Am J Surg Pathol 32(10):1495-502

53. Schwartz EJ, Molina-Kirsch H, Zhao S, Marinelli RJ, Warnke RA, Natkunam Y (2008) Immunohistochemical characterization of nasal-type extranodal NK/T-cell lymphoma using a tissue microarray: an analysis of 84 cases. Am J Clin Pathol 130 (3):343-351

54. Riou-Gotta MO, Fournier E, Mermet I, Pelletier F, Humbert P, Danzon A, Aubin F (2008) Primary cutaneous lymphomas: a population-based descriptive study of 71 consecutive cases diagnosed between 1980 and 2003. Leuk Lymphoma 49 (8): $1537-1544$

55. van Maldegem F, van Dijk R, Wormhoudt TA, Kluin PM, Willemze R, Cerroni L, van Noesel CJ, Bende RJ (2008) The majority of cutaneous marginal zone B-cell lymphomas expresses class-switched immunoglobulins and develops in a Thelper type 2 inflammatory environment. Blood 112(8):33553361 
56. Kempf W, Ostheeren-Michaelis S, Paulli M, Lucioni M, Wechsler J, Audring H, Assaf C, Rüdiger T, Willemze R, Meijer CJ, Berti E, Cerroni L, Santucci M, Hallermann C, Berneburg M, Chimenti S, Robson A, Marschalko M, Kazakov DV, Petrella T, Fraitag S, Carlotti A, Courville P, Laeng H, Knobler R, Golling P, Dummer R, Burg G (2008) Cutaneous lymphoma histopathology task force group of the European Organization for Research and Treatment of cancer. Granulomatous mycosis fungoides and granulomatous slack skin: a multicenter study of the cutaneous lymphoma histopathology task force group of the European Organization For Research and Treatment of Cancer (EORTC). Arch Dermatol 144(12):1609-1617

57. Sato Y, Ohshima K, Ichimura K, Sato M, Yamadori I, Tanaka T, Takata K, Morito T, Kondo E, Yoshino T (2008) Ocular adnexal IgG4-related disease has uniform clinicopathology. Pathol Int 58 (8):465-470

58. Gładkowska-Dura M, Dzierzanowska-Fangrat K, Dura WT, van Krieken JH, Chrzanowska KH, van Dongen JJ, Langerak AW (2008) Unique morphological spectrum of lymphomas in Nijmegen breakage syndrome (NBS) patients with high frequency of consecutive lymphoma formation. J Pathol 216(3):337-344

59. Lenz G, Wright G, Dave SS, Xiao W, Powell J, Zhao H, Xu W, Tan B, Goldschmidt N, Iqbal J, Vose J, Bast M, Fu K, Weisenburger DD, Greiner TC, Armitage JO, Kyle A, May L, Gascoyne RD, Connors JM, Troen G, Holte H, Kvaloy S, Dierickx D, Verhoef G, Delabie J, Smeland EB, Jares P, Martinez A, Lopez-Guillermo A, Montserrat E, Campo E, Braziel RM, Miller TP, Rimsza LM, Cook JR, Pohlman B, Sweetenham J, Tubbs RR, Fisher RI, Hartmann E, Rosenwald A, Ott G, MullerHermelink HK, Wrench D, Lister TA, Jaffe ES, Wilson WH, Chan WC, Staudt LM (2008) Lymphoma/Leukemia Molecular Profiling Project. Stromal gene signatures in large-B-cell lymphomas. N Engl J Med 359(22):2313-2323

60. Wong KK, Prepageran N, Peh SC (2008) Prognostic subgroup distribution in diffuse large B-cell lymphoma of the upper aerodigestive tract. Pathology 29:1-7

61. Dunphy CH, O’Malley DP, Cheng L, Fodrie TY, Perkins SL, Kaiser-Rogers KK (2008) Primary mediastinal B-cell lymphoma: detection of bcl-2 gene rearrangements by PCR analysis and FISH. J Hematopathol 1:77-84

62. Kleinschmidt-DeMasters BK, Damek DM, Lillehei KO, Dogan A, Giannini C (2008) Epstein Barr virus-associated primary CNS lymphomas in elderly patients on immunosuppressive medications. J Neuropathol Exp Neurol 67(11):1103-1111

63. Katzenberger T, Kalla J, Leich E, Stocklein H, Hartmann E, Barnickel S, Wessendorf S, Ott MM, Muller-Hermelink HK, Rosenwald A, Ott G (2009) A distinctive subtype of $\mathrm{t}(14 ; 18)$ negative nodal follicular non-Hodgkin lymphoma characterized by a predominantly diffuse growth pattern and deletions in the chromosomal region 1p36. Blood 113(5):1053-1061

64. Booman M, Szuhai K, Rosenwald A, Hartmann E, KluinNelemans H, de Jong D, Schuuring E, Kluin P (2008) Genomic alterations and gene expression in primary diffuse large B-cell lymphomas of immune-privileged sites: the importance of apoptosis and immunomodulatory pathways. J Pathol 216 (2):209-217

65. Sato Y, Onishi N, Morito T, Takata K, Mizobuchi K, Nagatsuka H, Ichimura K, Tanaka T, Tamura M, Yoshino T (2009) Patients with localized primary non-tonsillar oral diffuse large B-cell lymphoma exhibit favorable prognosis despite a non-germinal center B-cell-like phenotype. Cancer Sci 100(1):42-46

66. Magro CM, Schaefer JT, Morrison C, Porcu P (2008) Atypical lymphocytic lobular panniculitis: a clonal subcutaneous T-cell dyscrasia. J Cutan Pathol 35(10):947-954

67. Akiyama $\mathrm{T}$, Okino $\mathrm{T}$, Konishi $\mathrm{H}$, Wani $\mathrm{Y}$, Notohara $\mathrm{K}$, Tsukayama C, Tsunoda T, Tasaka T, Masaki Y, Sugihara T,
Sadahira Y (2008) CD8+, CD56+ (natural killer-like) T-cell lymphoma involving the small intestine with no evidence of enteropathy: clinicopathology and molecular study of five Japanese patients. Pathol Int 58(10):626-634

68. de Jong D, Vasmel WL, de Boer JP, Verhave G, Barbé E, Casparie MK, van Leeuwen FE (2008) Anaplastic large-cell lymphoma in women with breast implants. JAMA 300 (17):2030-2035

69. Mosunjac MB, Sundstrom JB, Mosunjac MI (2008) Unusual presentation of anaplastic large cell lymphoma with clinical course mimicking fever of unknown origin and sepsis: autopsy study of five cases. Croat Med J 49(5):660-668

70. Rodríguez-Pinilla SM, Atienza L, Murillo C, Pérez-Rodríguez A, Montes-Moreno S, Roncador G, Pérez-Seoane C, Domínguez P, Camacho FI, Piris MA (2008) Peripheral T-cell lymphoma with follicular T-cell markers. Am J Surg Pathol 32(12):1787-1799

71. LaCasce AS, Kho ME, Friedberg JW, Niland JC, Abel GA, Rodriguez MA, Czuczman MS, Millenson MM, Zelenetz AD, Weeks JC (2008) Comparison of referring and final pathology for patients with non-Hodgkin's lymphoma in the National Comprehensive Cancer Network. J Clin Oncol 26(31):51075112

72. Kojima M, Shimizu K, Ikota H, Ohno Y, Motoori T, Itoh H, Masawa N, Nakamura S (2008) "Follicular Variant" of Hyalinevascular Type of Castleman's Disease: histopathological and Immunohistochemical Study of 11 Cases. J Clin Exp Hematop 48(2):39-45

73. Wang J, Chen C, Lau S, Raghavan RI, Rowsell EH, Said J, Weiss LM, Huang Q (2009) CD3-positive Large B-cell Lymphoma. Am J Surg Pathol (in press)

74. Rahemtullah A, Longtine JA, Harris NL, Dorn M, Zembowicz A, Quintanilla-Fend L, Preffer FI, Ferry JA (2008) CD20+ T-cell lymphoma: clinicopathologic analysis of 9 cases and a review of the literature. Am J Surg Pathol 32(11):1593-1607

75. Schreck S, Friebel D, Buettner M, Distel L, Grabenbauer G, Young LS, Niedobitek G (2008) Prognostic impact of tumourinfiltrating $\mathrm{Th} 2$ and regulatory $\mathrm{T}$ cells in classical Hodgkin lymphoma. Hematol Oncol (in press)

76. Dong G, Liu C, Ye H, Gong L, Zheng J, Li M, Huang X, Huang X, Huang Y, Shi Y, Yin W, Gao Z (2008) BCL10 nuclear expression and $\mathrm{t}(11 ; 18)(\mathrm{q} 21 ; \mathrm{q} 21)$ indicate nonresponsiveness to Helicobacter pylori eradication of Chinese primary gastric MALT lymphoma. Int J Hematol 88(5):516-523

77. Wang X, ASP Lund AC, Porwit A, Flygare J, Smith CI, Christensson B, Sander B (2008) The subcellular Sox11 distribution pattern identifies subsets of mantle cell lymphoma: correlation to overall survival. Br J Haematol 143(2):248-252

78. Sar A, Perizzolo M, Stewart D, Mansoor A, Difrancesco LM, Demetrick DJ (2009) Mutation or polymorphism of the CD20 gene is not associated with the response to R-CHOP in diffuse large B cell lymphoma patients. Leuk Res (in press)

79. Aktaș S, Kargı A, Olgun N, Diniz G, Erbay A, Vergin C (2009) Prognostic significance of cell proliferation and apoptosisregulating proteins in Epstein-Barr virus positive and negative pediatric non-Hodgkin's lymphoma. Pathol Oncol Res (in press)

80. Lenz G, Wright GW, Emre NC, Kohlhammer H, Dave SS, Davis RE, Carty S, Lam LT, Shaffer AL, Xiao W, Powell J, Rosenwald A, Ott G, Muller-Hermelink HK, Gascoyne RD, Connors JM, Campo E, Jaffe ES, Delabie J, Smeland EB, Rimsza LM, Fisher RI, Weisenburger DD, Chan WC, Staudt LM (2008) Molecular subtypes of diffuse large B-cell lymphoma arise by distinct genetic pathways. Proc Natl Acad Sci USA 105(36):1352013525

81. Peh SC, Gan GG, Lee LK, Eow GI (2008) Clinical relevance of CD10, BCL-6 and multiple myeloma-1 expression in diffuse large B-cell lymphomas in Malaysia. Pathol Int 58(9):572-579 
82. Johnson NA, Boyle M, Bashashati A, Leach S, Brooks-Wilson A, Sehn LH, Chhanabhai M, Brinkman RR, Connors JM, Weng AP, Gascoyne RD (2009) Diffuse large B cell lymphoma: reduced $\mathrm{CD} 20$ expression is associated with an inferior survival. Blood (in press)

83. Hsi ED, Jung SH, Lai R, Johnson JL, Cook JR, Jones D, Devos S, Cheson BD, Damon LE, Said J (2008) Ki67 and PIM1 expression predict outcome in mantle cell lymphoma treated with high dose therapy, stem cell transplantation and rituximab: a Cancer and Leukemia Group B 59909 correlative science study. Leuk Lymphoma 49(11):2081-2090

84. Hasselblom S, Ridell B, Sigurdardottir M, Hansson U, Nilsson-Ehle H, Andersson PO (2008) Low rather than high $\mathrm{Ki}-67$ protein expression is an adverse prognostic factor in diffuse large B-cell lymphoma. Leuk Lymphoma 49(8):15011509

85. Jang KY, Hwang SH, Kwon KS, Kim KR, Choi HN, Lee NR, Kwak JY, Park BH, Park HS, Chung MJ, Kang MJ, Lee DG, Kim HS, Shim H, Moon WS (2008) SIRT1 expression is associated with poor prognosis of diffuse large B-cell lymphoma. Am J Surg Pathol 32(10):1523-1531

86. Johnson NA, Al-Tourah A, Brown CJ, Connors JM, Gascoyne RD, Horsman DE (2008) Prognostic significance of secondary cytogenetic alterations in follicular lymphomas. Genes Chromosomes Cancer 47(12):1038-1048

87. Hasselblom S, Hansson U, Sigurdardottir M, Nilsson-Ehle H, Ridell B, Andersson PO (2008) Expression of CD68+ tumorassociated macrophages in patients with diffuse large B-cell lymphoma and its relation to prognosis. Pathol Int 58(8):529532

88. Aggarwal M, Villuendas R, Gomez G, Rodriguez-Pinilla SM, Sanchez-Beato M, Alvarez D, Martinez N, Rodriguez A, Castillo ME, Camacho FI, Montes-Moreno S, Garcia-Marco JA, Kimby E, Pisano DG, Piris MA (2009) TCL1A expression delineates biological and clinical variability in B-cell lymphoma. Mod Pathol 22(2):206-215

89. Klapper W, Stoecklein H, Zeynalova S, Ott G, Kosari F, Rosenwald A, Loeffler M, Trümper L, Pfreundschuh M, Siebert R (2008) German High-Grade Non-Hodgkin's Lymphoma Study Group. Structural aberrations affecting the MYC locus indicate a poor prognosis independent of clinical risk factors in diffuse large B-cell lymphomas treated within randomized trials of the German High-Grade Non-Hodgkin's Lymphoma Study Group (DSHNHL). Leukemia 22(12):2226-2229

90. Yoon SO, Jeon YK, Paik JH, Kim WY, Kim YA, Kim JE, Kim CW (2008) MYC translocation and an increased copy number predict poor prognosis in adult diffuse large B-cell lymphoma (DLBCL), especially in germinal centre-like B cell (GCB) type. Histopathology 53(2):205-217

91. Wang B, Li XQ, Ma X, Hong X, Lu H, Guo Y (2008) Immunohistochemical expression and clinical significance of Pglycoprotein in previously untreated extranodal NK/T-cell lymphoma, nasal type. Am J Hematol 83(10):795-799
92. Seegmiller AC, Karandikar NJ, Kroft SH, McKenna RW, Xu Y (2009) Overexpression of CD7 in classical Hodgkin lymphomainfiltrating $\mathrm{T}$ lymphocytes. Cytometry B Clin Cytom (in press)

93. Pierson DM, Jones D, Muzzafar T, Kersh MJ, Challagundla P, Medeiros LJ, Jorgensen JL (2008) Utility of CD26 in flow cytometric immunophenotyping of T-cell lymphomas in tissue and body fluid specimens. Cytometry B Clin Cytom 74(6):341348

94. van Rijk A, Mason D, Jones M, Cabeçadas J, Crespo M, Cigudosa JC, Garcia JF, Leoncini L, Cocco M, Hansmann M-L, Mottok A, Bergman CC, Gaulard P, Anagnostou D, Pouliou E, Dutoit SH, Christiansen MH, Mathiessen S, Poulsen TS, van Dongen J, van Krieken JH (2008) Translocation detection in lymphoma diagnosis by split-signal FISH: a standardised approach. J Hematopathol 1:119-126

95. Flanagan MB, Sathanoori M, Surti U, Soma L, Swerdlow SH (2008) Cytogenetic abnormalities detected by fluorescence in situ hybridization on paraffin-embedded chronic lymphocytic leukemia/small lymphocytic lymphoma lymphoid tissue biopsy specimens. Am J Clin Pathol 130(4):620-627

96. Huh HJ, Min HC, Cho HI, Chae SL, Lee DS (2008) Investigation of bone marrow involvement in malignant lymphoma using fluorescence in situ hybridization: possible utility in the detection of micrometastasis. Cancer Genet Cytogenet 186(1):1-5

97. Groenen PJTA, Langerak AW, van Dongen JJM, van Krieken JHJM (2008) Pitfalls in TCR gene clonality testing: teaching cases. J Hematopathol 1:97-109

98. Santón A, García-Cosio M, Bellosillo B, Rodríguez P, Cristóbal E, Serrano S, Besses C, Abraira V, Salar A, Montalbán C (2008) Persistent monoclonality after histological remission in gastric mucosa-associated lymphoid tissue lymphoma treated with chemotherapy and/or surgery: influence of $\mathrm{t}(11 ; 18)(\mathrm{q} 21 ; \mathrm{q} 21)$. Leuk Lymphoma 49(8):1516-1522

99. Morales AV, Arber DA, Seo K, Kohler S, Kim YH, Sundram UN (2008) Evaluation of B-cell clonality using the BIOMED-2 PCR method effectively distinguishes cutaneous B-cell lymphoma from benign lymphoid infiltrates. Am J Dermatopathol 30 (5):425-430

100. Tan BT, Seo K, Warnke RA, Arber DA (2008) The frequency of immunoglobulin heavy chain gene and T-cell receptor gammachain gene rearrangements and Epstein-Barr virus in ALK+ and ALK- anaplastic large cell lymphoma and other peripheral T-cell lymphomas. J Mol Diagn 10(6):502-512

101. Pai RK, Mullins FM, Kim YH, Kong CS (2008) Cytologic evaluation of lymphadenopathy associated with mycosis fungoides and Sezary syndrome: role of immunophenotypic and molecular ancillary studies. Cancer 114(5):323-332

102. Caraway NP, Thomas E, Khanna A, Payne L, Zhang HZ, Lin E, Keating MJ, Katz RL (2008) Chromosomal abnormalities detected by multicolor fluorescence in situ hybridization in fine-needle aspirates from patients with small lymphocytic lymphoma are useful for predicting survival. Cancer 114 (5):315-322 